\title{
FOLLOWING THE TRAIL OF MUSICAL MANUSCRIPTS AND PRINTS BELONGING TO THE MONASTIC ORDERS AT PTUJ
}

\author{
DARJA KOTER \\ Akademija za glasbo, Univerza v Ljubljani
}

\begin{abstract}
Izvleček: Problematika o uporabi, širjenju in dediščini historičnih glasbenih rokopisov in tiskov na širšem evropskem prostoru je prepoznavna tudi skozi delovanje in glasbeno poslanstvo dominikanskega in minoritskega samostana na Ptuju. Obe nekoč izjemno pomembni redovni skupnosti sta bili tesno vpeti vevropska duhovna gibanja. Ohranjena glasbeno-teoretična dela, liturgične knjige in posamezni foliji omogočajo podrobnejše poznavanje glasbene kulture obeh redovnih skupnosti in medkulturnih vplivov, ki so bili posledica pestre migracije redovnikov med samostani obeh redov.
\end{abstract}

Ključne besede: dominikanski samostan Ptuj, minoritski samostan Ptuj, glasbeni rokopisi, glasbeni tiski, migracija redovnikov.

\begin{abstract}
The paper focuses on issues concerned with the heritage of historical music manuscripts and prints, along with their use and dissemination in the wider European area, as well as the activities and musical mission of the Dominican and Minorite monasteries in Ptuj (Pettau, Petovio). Both monastic orders were once exceptionally important and maintained strong connections with European spiritual movements. They preserved works on music theory, liturgical books and some sheet music, which has enabled a more detailed insight into the musical culture of monastic communities and into the transcultural influences that resulted from the multi-directional migrations of friars among various European monasteries in the past.
\end{abstract}

Keywords: Dominican monasteries in Ptuj, Minorite monasteries in Ptuj, music manuscripts and prints, migration of friars.

There are a number of manuscripts and printed books in many archives and libraries with open questions about their provenance. Determination of their origin and the wider question of the former ownership of cultural heritage are important subjects for research. Exploring these issues may lead us to enrich our knowledge and understanding of the cultural backgrounds and spiritual movements in relation to which these items were produced. Among other questions, there are many unknowns attending the musical manuscripts and prints associated with the history of monasteries or convents. One of the factors we have to take into account when researching in this area is the migration of friars, who generally moved between monasteries, and thereby influenced the circulation of musical material. 
It is well known that European monasteries had rich libraries, which were continually supplemented by the individuals circulating between houses - something that is also true of monasteries in today's Slovenia. Several monasteries of the most prominent European orders were established in Slovenia from the thirteenth century onwards, among them the Dominican and Minorite monasteries in Ptuj (Ger. Pettau, Lat. Petovio). Both of these institutions influenced the spiritual, economic, educational and cultural level of the town and its surroundings.

Unfortunately, there is little left of the Ptuj monasteries' musical heritage as a result of numerous fires, the influence of the Reformation and Counter-Reformation, the reforms of Emperor Joseph II, the migration of friars and other factors. Nevertheless, the preserved sources are sufficiently rich to provide answers to the questions about the movement of musical literature circulated over the centuries. Previous studies have drawn attention to the frequent migration of friars belonging to both orders, and, as a result, some material related to the Ptuj monasteries is today preserved in archives and libraries in Graz, Vienna and elsewhere. ${ }^{1}$

The traces of most of it are, unfortunately, lost. For that reason, most attention will be paid to the general migration of Dominicans and Minorites from the foundation of the monasteries in the thirteenth century to the second half of the eighteenth century and the reforms of Joseph II in the 1780s, respectively. In addition to their main mission, both monasteries played a strong educational role from an elementary to an advanced level. Therefore, their lecturers and professors often became associated with musical activities, as is evident from the preserved richly detailed archival sources and music books. ${ }^{2}$

The Dominican order was founded in 1216, and friars were entrusted with pastoral care, preaching and confessing. They emphasized the importance of the study of theology and other sciences, the education of youth from an elementary to an advanced level and economic development. As a rule, they did not commit for life to the monastery in which they took their monastic vows, as required by the Benedictines, Carthusians and Cistercians. On the contrary, most of them operated in accordance with the temporary needs of a individual monastery within an individual province, which is one reason for their frequent migration.

In 1221 the General Chapter founded eight provinces, among them - on the territory of the land north of the Alps between France, Hungary and Poland - the so-called German province (Provinz Teutonia, Provincia Teotonia). ${ }^{3}$ The Cologne monastery, centre of the above-mentioned province, incorporated the monastery in Friesach in Carinthia, the first one on Slovenian ethnic territory (1217), in Ptuj. The growth of the monasteries in the following centuries led to numerous reforms. On the territory of the German province several

1 The author acknowledges the financial support from the state budget by the Slovenian Research Agency (project no. P6-0376).

The main references to the Dominican and Minorite monasteries in Ptuj are Kovačič, Dominikanski samostan; Mlinarič and Curk, Dominikanski samostan na Ptuju; Kovačič, "K starejši zgodovini," 149-168; Godina, 700-letnica minoritskega samostana; Mlinarič and Vogrin, Minoritski samostan.

2 Koter, "Glasbeno življenje," 121-132; Koter, "Glasbeni tiski in rokopisi," 101-112.

3 Hinnebuch, Dominikanci, 1-14. 
monasteries were established in the Styrian and Carinthian areas. The most important of them was Friesach, whose teaching friars established the Ptuj monastery, followed by monasteries in Leoben (late thirteenth century), Novi Klošter (Ger. Neukloster) near Polzela (1453) and Graz (1466). ${ }^{4}$

All these institutions were closely linked; however, the migration of friars was not limited to these monasteries; it also took place between others in the province and beyond. The Ptuj monastery was founded in 1230 by the Archbishop of Salzburg, Eberhard II (1200-1246), and the widow of the lord of Ptuj Frederick III, Mathilda (d. 1253), who donated land and funds for its building. ${ }^{5}$ The first teaching friars came to Ptuj from Friesach, which was known for its advanced studies in theology, law and philosophy. However, the general studies provided by the order took place in Basel. According to its Rule, each religious community had to provide an adequate education for novices as preparation for their general studies. Records regarding lectures and professors, as well as their level of education, suggest that before the establishment of the so-called high school there was a monastic school in Ptuj that may have been in operation from the fourteenth or fifteenth centuries or later. ${ }^{6}$

Although the data are inconclusive, the chronicles suggest that besides local "teaching" friars, ones from other monasteries in the province lectured in Ptuj: these came, for example, from Krems, Leoben, Graz, Hainburg, Villach, Zwettl and even Siena and Bologna. Further, some friars from Ptuj were entitled to a higher level of education and were sent to Vienna or even to renowned Italian monasteries such as Bologna, Padua and Siena. Evidence of the migration of friars belonging to several orders has been found: from Ptuj to Florence, Bolzano, Nuremberg and Zagreb, and to Ptuj from Vienna and Köln. ${ }^{7}$ The Reformation brought a significant reduction in the number of monasteries in the Hungarian province, and the rest of the communities were incorporated into the Styrian and Carinthian bodies.

The chronicler of the Order in Ptuj, Ambrosio Capello (author of the chronicle for the year 1697), wrote that monastic life in Ptuj stood no comparison with the "devastation" of monasteries in Germany and the surrounding area. ${ }^{8}$ In the mid-sixteenth century the Ptuj monastery was instructed to educate novices for the Hungarian province, which

4 The most significant source concerning the Dominicans in Ptuj is the monograph Mlinarič and Curk, Dominikanski samostan na Ptuju, which is based on research into all the important archival records, published sources and literature. For the history of the Dominican order in Styria, see the chapter by Mlinarič "Dominikanski red," in Mlinarič and Curk, Dominikanski samostan na Ptuju, 22-28.

5 See the chapter by Mlinarič, "Ustanavljanje samostana," in Mlinarič and Curk, Dominikanski samostan na Ptuju, 35-42.

6 The organization of study in the Ptuj monastery during the fourteenth century is discussed by Mlinarič in his chapter "Študij pri dominikancih," in Mlinarič and Curk, Dominikanski samostan na Ptuju, 65-67.

7 See Mlinarič, "Seznami dominikancev," in Mlinarič and Curk, Dominikanski samostan na Ptuju, 234-247.

8 Mlinarič, "Samostan v obdobju duhovne," in Mlinarič and Curk, Dominikanski samostan na Ptuju, 118. 
resulted in the wider circulation of Dominican ideas as well as of those manuscripts and prints that were customarily the private property of friars.

Sources from the sixteenth century record that the monastery then counted twelve friars and four novices, mainly from Hungary and Croatia. Some were of German origin, while others had come from Croatia to escape the Turkish threat. In addition, there were some Italian priors - a consequence of the Dominican superiors' distrust of domestic friars on account of the influence of the Reformation. ${ }^{9}$

From the beginning of the next century, parallel to the Counter-Reformation and political tensions between the Habsburgs and Venetians, friars stopped arriving from Italy. In the seventeenth century some monasteries in certain provinces managed to recover from Turkish pillaging and from Lutheranism, a development that encouraged the re-establishment of the monastic discipline. From the mid-sixteenth century all the Dominican monasteries in Styria and Friesach in Carinthia, as well as some in Hungary, were incorporated into the Hungarian province. Since by the beginning of the next century all the friars in Hungary had passed away, the Province no longer had any reason to exist.

In 1611 the monastic superiors annexed all monasteries of "German" origin to the German religious province. Until the abolition of the Dominican monastery in Ptuj the majority of its priors and friars had been of Italian, German, Croatian, Dalmatian and even Belgian origin. There is also evidence for the presence of numerous novices who were educated there for the Graz, Vienna, Szombathely, Leoben, Novi Klošter and Friesach monasteries; it should also be pointed out that some students came from the local area, while others were sent to Ptuj as guests or were merely in transit there. ${ }^{10}$

During the eighteenth century the Ptuj monasteries of the Dominican, Minorite and Capuchin orders took charge of elementary education and of the so-called high schools and in particular of scholars from the town and its surrounding areas. The records attest to the large number of well-educated friars, priors, lecturers and professors from the locality and beyond. ${ }^{11}$

A variety of documents and chronicles contain evidence of musical activity in the monastery. The monastery had its own bindery and a rich library with a wide range of literature, although, unfortunately, only about thirty-two manuscripts are preserved - the number of musical manuscripts and books is not known. The catalogue of 1782, drawn up not long before the dissolution of the monastery in 1786, mentions approximately nine hundred works, which may actually be a conservative figure, considering the effect of the many fires and the migration of friars, teachers and lay-brothers. After the dissolution of the monastery some manuscripts and books passed to the University Library in Graz, while the majority was lost or is preserved in unknown locations. ${ }^{12}$

9 Ibid., 121.

${ }^{10}$ Mlinarič, "Upravna preureditev," in Mlinarič and Curk, Dominikanski samostan na Ptuju, 141-163.

${ }^{11}$ Regarding the Dominican monastery during the eighteenth century, see Mlinarič, "Skozi življenje ptujskega samostana," in Mlinarič and Curk, Dominikanski samostan na Ptuju, 195-205.

${ }^{12}$ Kovačič, Dominikanski samostan, 120-125; Mlinarič, "Samostanska knjižnica," 230-233. 
Each monastery usually focused on high-level musical culture. This was especially true of those housing a school. In accordance with the artes liberales, novices were educated in Gregorian chant for the needs of the liturgical ceremonial. The records state that the members of the Ptuj monastery sang the complete Office and Requiem Masses from the mid-fifteenth century onwards. ${ }^{13}$ In 1641 the Prior engaged a lay-brother organist as accompanist for the friars' choral singing on Sundays and feast days. ${ }^{14}$

The monastery church possessed an organ from as early as 1458 , while there is a reference in the records from 1664 to a new "large" organ; however, the only organist known by name is Franz Xaver Resch from Graz, mentioned in Ptuj between 1757 and 1783. In the inventory of 1786 we find mention of an organ with six registers, which could be an old musical instrument that has not been preserved. ${ }^{15}$ Organs of this kind entered use in the mid-seventeenth century up to the first half of the eighteenth century, although they were already outdated by the time the monastery was dissolved.

The monastery of the Friars Minor in Ptuj was founded by the Lords of Ptuj around 1239. During its first few centuries it was materially dependent on them, as was the Dominican monastery. The relevant diocesan authorities provided the two houses, along with the right to carry out pastoral duties, preaching and confession. Because of its solid financial status, achieved through donations from aristocratic families, the number of friars (priests and lay-brothers) steadily grew.

In the medieval period the Ptuj monastery came under the jurisdiction of the Austrian Province (founded during the second half of the thirteenth century), which had eighteen monasteries and close links to others. A number of priors accordingly came to Ptuj from other monasteries and provinces (Tulln, Enns, Wells etc.). ${ }^{16}$

The Reformation at the beginning of the sixteenth century brought about a reduction in the number of monasteries. The new circumstances required a re-organisation of the Austrian Province, given that in 1553 only seven friars lived at the monastery in Vienna and the same number in Ptuj. This would explain the presence in Ptuj of friars from Mediterranean countries, particularly Italy and Dalmatia. Following a reform of the order in the first half of the sixteenth century, a Styrian Province was established. The Ptuj monastery served as its headquarters for some time: in fact, right up to 1607.

Before 1668 the Styrian Province included monasteries in Maribor, Celje, Ptuj, Bruck an der Mur, Judenburg, Graz, Villach and even Trieste and Gorizia. From the end of the sixteenth to the mid-seventeenth century most of the guardians and friars in Ptuj were of Italian origin. The majority of them arrived as a consequence of the strength of the Lutheran movement, while others were descended from Italian families that had moved to Ptuj in the sixteenth and seventeenth centuries.

${ }^{13}$ Mlinarič and Curk, Dominikanski samostan na Ptuju, 78, 82, 85, 121, 152.

${ }^{14}$ In Mlinarič, "Skozi življenje ptujskega samostana," in Mlinarič and Curk, Dominikanski samostan na Ptuju, 152.

${ }^{15}$ There are very few records of organs and organists in the archives. See Kovačič, Dominikanski samostan, 16-48; Mlinarič and Curk, Dominikanski samostan, 20, 152, 158, 214 and 216.

${ }^{16}$ Regarding the Lords of Ptuj, see Vidmar, "Die Herren von Pettau." 
The heavy migration of Italians to Ptuj, particularly among builders, stonemasons and bricklayers, was connected with the Turkish threat, which accelerated the building of defensive walls. A new wave of migration took place at the beginning of the seventeenth century, at the time of the Counter-Reformation, when Lutheran families (tradesmen and merchants) from Ptuj moved away towards the north and were replaced by Italians. From the second half of the seventeenth century there are no records of guardians and friars of Italian origin: the majority of them were of German, and some of Slovenian, origin.

One of the characteristics of the Minorite order was the circulation of friars between the monasteries of a particular province. As well as noting that since 1607 Graz had played the leading role within the Province, it is also necessary to stress that the Ptuj monastery, one of the larger ones, also played an important religious, spiritual, economic and educational role. It has already been established that from the mid-eighteenth century it had twenty-two members, friars, clerics and lay-brothers. Among the most common duties of the friars were to act as organist, music teacher, master of novices, festive preacher, archivist or librarian.

Following the reorganization of educational activities in the period of the reforms carried out by Joseph II, the Ptuj Minorite monastery survived, while the majority of its sister houses were dissolved. The list of the monastery's members in 1788 proves that the majority of friars and lay-brothers were of German origin; however, they came to Ptuj from Carinthia, Bohemia, Hungary and Austria, as well as from Ptuj and its surroundings. ${ }^{17}$

Little is known about the musical activities of the Ptuj Friars Minor, their heritage of music manuscripts, prints and the influence of migration. The most important source of information is the monastery library, with its nearly five thousand units from the early sixteenth century onwards, which contained musical manuscripts and prints. We can also consult the archival records of the activities and migration of friar musicians, which provide information on regentes chori, organists and other instrumentalists. ${ }^{18}$ It is known that the content of the library was affected by the migration of monastery members, as well by its destruction, which occurred during the Counter-Reformation.

The preserved heritage points to the influence of the inward migration of guardians and friars from Italian monasteries during the sixteenth and early seventeenth centuries. ${ }^{19}$ Among the preserved objects is a Bible, published in 1553 in Venice, which is enclosed in parchment paper with a choral notation datable to the end of the fifteenth century - a characteristic of the late medieval period under the influence of German scriptoriums. ${ }^{20}$ The preserved Bible with its parchment paper fragment could possibly be connected with the movement of friars from Italian and Dalmatian monasteries to Ptuj. After the invention of printing the use of folios with musical manuscripts as endpapers became common, particularly during the mid-sixteenth century but also throughout the next two centuries.

${ }^{17}$ Mlinarič, "Ptujski samostan v zadnjih dveh stoletjih," 140-163, 172-173 and 195-205; Mlinarič, "Ukinitev samostana v letu 1786," 212-218.

${ }^{18}$ Mlinarič and Vogrin, Minoritski samostan; Koter, "Glasbeno življenje," 126-128; Koter, "Glasbeni tiski," 102-108.

${ }^{19}$ Mlinarič, "Zgodovina samostana od ustanovitve do 1800," 47-86.

${ }^{20}$ Koter, "Glasbeni tiski," 103-105. 
As the parchment has only partially been preserved, I am unable to establish the precise content of the unknown codex or its origin.

There are also some unanswered questions regarding the ex libris in the book: "Patris Constantin Wutt de Pettovio Ord. Minor. Conventual" (MK1459 L VI). The friar Constantin Wutt (1710-1770), born in Maribor, was active in several Styrian monasteries (Graz, Celje, Maribor) and a guardian of the Ptuj monastery. According to the records, he was, in particular, a renowned musician, regens chori and even a composer. ${ }^{21}$ The abovementioned copy of the Bible, which contains numerous depictions of musical instruments as a symbol of the glory of music, serves as a good example of how complicated researching heritage trails can be.

The second of the significant examples from the library of the Ptuj Minorites is a first edition from 1558 of Gioseffo Zarlino's remarkable theoretical work Le istitutioni harmoniche (MK $584 \mathrm{E}$ V. The numerous handwritten inscriptions and musical notes in the book, made by several users, attest to its theoretical and practical importance and frequent use. The volume contains an ex libris with the legend "Conventum Petoviensis" (Ptuj Monastery) and a painting (probably from 1695) showing SS Peter and Paul, patrons of the Minorite monastery church. Above the picture is a record of the author of the painting and/or owner of the book (“Opera Fris. Anselmi P. Lueber in [...] Contu. Pettouiens. Min. Conv. 1695”). These musical sources most likely evidence the friars' curiosity about music theory, which is only to be expected for the Ptuj monastery.

Also interesting is a volume with theological treatises by Joseph Langio from 1681 (MK 2433 V VI) enclosed in parchment paper with a Gothic plainsong notation datable to the end of the fifteenth or the beginning of the sixteenth century, characteristic of the Salzburg archdiocese. Unfortunately, the provenance of the fragment is unclear, but its content is possibly a section of the Gloria from the Ordinary of the Mass. The following inscription is visible on the title page: "Fr. Constantin Halleg de Pettovia, guem[...] 22.Otobris 1693". The named person could be one of the owners of the book, but there is no record of his origin or education.

Among other items, some seventeenth-century liturgical books, most of them prints from Venice, have been preserved. The traces on some of the pages, particularly of some fragments of Mattins and the Mass, serve as eloquent evidence of their frequent use. Among them should be mentioned a Psalterium Romanum (1667), a Graduale Romanum (1662), a Missale Romanum (1622) and an Antiphonarium Romanum (1687). The lastmentioned volume, a daily prayer book, contains numerous handwritten fragments with musical notes, names of friars etc.

In conclusion, we can see that archival records pertaining to the frequent migration of Dominicans and Minorites and their musical education and activities, such as preserved manuscripts and prints, are able to supplement our knowledge about the circulation of musical sources. Regarding both monasteries in Ptuj, it has already been established that the friars, priors, guardians and lay-brothers were well-educated, and that some of them were active as regentes chori, musicians, rectors, organists, instrumentalists and even composers. In accordance with the rules of both orders, most of the residents were

${ }^{21}$ Emeršič, Minoritska knjižnica, 30; Koter, “Glasbeni tiski,” 105. 
members of various monasteries stretching along a west-east axis from Germany and Italy to Hungary and along a north-south axis from Vienna to Dalmatia.

The patterns of circulation between monasteries prove that Ptuj stood at a crossroads of spiritual trails from the medieval period onwards, exactly as in Roman times. Both monastic orders were once exceptionally important and maintained strong connections with Central European monasteries; their many-sided activities accordingly contributed to the spiritual, economic, educational and cultural level of the local area and its wider surroundings. Members of the monasteries were well-educated men coming from noble families, mostly with German, Italian, Hungarian, Slovenian or Croatian backgrounds. The preserved documents afford a more detailed insight into the musical culture of monastic communities and into the transcultural influences resulting from the multi-directional migrations of friars between various monasteries in the Europe of the past.

\section{Bibliography}

Emeršič, Jakob. Minoritska knjižnica na Ptuju. Sostro: Minoritsko bogoslovno semenišče, 1989.

Godina, Mirko, ed. 700-letnica minoritskega samostana na Ptuju: Pax et bonum. Ptuj: Minoritski samostan, 1939.

Hinnebuch, William A. Dominikanci-kratka povijest reda. Zagreb: Globus, 1997.

Koter, Darja. "Glasbeni tiski in rokopisi 15. in 16. stoletja, ohranjeni na Ptuju.” In Statut mesta Ptuj iz leta 1513 / Das Stadtrecht von Ptuj (Pettau) aus dem Jahre 1513, edited by Marija Hernja Masten, 101-112. Ptuj: Zgodovinski arhiv, 2003.

____ “_Glasbeno življenje na Ptuju v 17. stoletju." In Dolarjev zbornik, edited by Edo Škulj, 121-132. Ljubljana: Družina, 2002.

Kovačič, Fran. "K starejši zgodovini minoritskega samostana v Ptuju." Časopis za zgodovino in narodopisje 22 (1927): 149-168.

___ Dominikanski samostan v Ptuju. Maribor: Tiskarna sv. Cirila, 1914.

Mlinarič, Jože. “Zgodovina samostana od ustanovitve do 1800.” In Minoritski samostan na Ptuju 1239-1989, edited by Jože Mlinarič and Marjan Vogrin, 47-86. Ptuj: Minoritski samostan and Celje: Mohorjeva družba, 1989.

and Jože Curk. Dominikanski samostan na Ptuju, edited by Marija Hernja Masten. Ptuj: Zgodovinski arhiv, 2009.

and Marjan Vogrin, eds. Minoritski samostan na Ptuju, 1239-1989. Ptuj: Minoritski samostan and Celje: Mohorjeva družba, 1989.

Vidmar, Polona. "Die Herren von Pettau als Bauherren und Mäzene.” PhD diss., KarlFranzens-Universität Graz, 2006. 


\section{PO SLEDEH GLASBENIH ROKOPISOV IN TISKOV PTUJSKIH MENIŠKIH REDOV}

\section{Povzetek}

Za temeljitejše poznavanje problematike o uporabi, širjenju in dediščini historičnih glasbenih rokopisov in tiskov na širšem evropskem prostoru je potrebno upoštevati tudi delovanje in glasbeno poslanstvo dominikanskega in minoritskega samostana na Ptuju. Obe nekoč izjemno pomembni redovni skupnosti sta bili tesno vpeti v evropska duhovna gibanja, s svojim večstranskim delovanjem pa sta vplivali tudi na duhovno, gospodarsko in kulturno raven lokalnega območja. Ptujski dominikanski samostan (1230-1786), ki je sodil k nemški, nato pa k avstrijski in ogrski provinci, deloma pa se je povezoval tudi z italijanskim in hrvaškim prostorom, je pomenil nekakšen most med srednjo Evropo in Ogrsko. Med člani konventov, ki so bili izobraženci iz plemiških družin nemškega, italijanskega, ogrskega, slovenskega in hrvaškega okolja, je potekala intenzivna migracija, ki je pomenila tudi izmenjavanje glasbenih praks in literature. Na Ptuj so prihajali redovniki iz Kremsa, Leobna, Gradca, Hainburga, Villacha, Zwettla, pa tudi iz Siene in Bologne. Nekateri so iz Ptuja odhajali na nadaljnji študij na Dunaj ali v renomirane italijanske samostane, kot so Bologna, Padova, Siena in drugi, migracija pa je potekala tudi z ogrskimi in s hrvaškimi oziroma dalmatinskimi mesti. O glasbeni dejavnosti ptujskega dominikanskega samostana pričajo različne listine, kronike in liturgične knjige. Konvent je imel lastno knjigoveznico in bogato knjižnico, vendar je njena vsebina le delno znana. Rokopise in knjige naj bi po razpustitvi samostana hranili v dunajski dvorni in graški licejski knjižnici, precej je zgubljenega.

Ptujski minoritski samostan sv. Petra in Pavla (ustanovljen okoli leta 1255) je drugi pomembnejši konvent za utrjevanje verskega življenja na današnjem slovenskem Štajerskem. V njem so Frančiškovi manjši bratje ob izpolnjevanju evangelija razvili samostansko, kasneje tudi javno šolstvo, kjer so med drugim poučevali glasbeno-liturgično petje in gojili instrumentalno oziroma vokalno-instrumentalno glasbo. Med najpomembnejšimi viri za poznavanje glasbene prakse ptujskega minoritskega samostana je njegova knjižnica s pet tisoč enotami, med katerimi so tudi glasbeni rokopisi in tiski od poznega 15. stoletja naprej. Med njimi so pergamentni rokopisi, posamezni beneški glasbeni tiski iz 16. in 17. stoletja in mašne knjige (antifonariji, misali, graduali, psalteriji). V nekaterih so ohranjeni ekslibrisi, ki kažejo na migracijo članov ptujskega minoritskega konventa z italijanskim prostorom in Dalmacijo. Arhivski viri pričajo tudi o aktivnostih regens chorijev, organistov in drugih instrumentalistov, pa tudi skladateljev, ki so si prizadevali za kulturni in umetniški razvoj svojega okolja. Tako kot velja za dominikance, so tudi minoriti prihajali na Ptuj iz različnih okolij. Posebno dejavno je bilo povezovanje z današnjo Italijo, kar je pomenilo svojevrstno kulturno migracijo in vplivalo na duhovno in kulturno podobo konventa in njegove glasbene prakse. Do danes ohranjena bogata minoritska knjižnica omogoča podrobnejše poznavanje glasbene kulture redovnih skupnosti in medkulturnih vplivov, ki so bili posledica pestre migracije redovnikov med različnimi samostani nekdanje Evrope. 